\title{
The from News Bearer to Extreme Speech Propagator: Analysis of Shifting Practice in Production and Distribution of News on the Internet
}

\author{
Rouli Manalu*1, Tandiyo Pradekso ${ }^{1}$, Djoko Setyabudi ${ }^{1}$ \\ ${ }^{1}$ The authors are lecturers at Department of Communication, Universitas Diponegoro, Central Java, Indonesia
}

\begin{abstract}
This research aims to examine the ways in which practices of information productions and distributions are shifting in the Internet era, particularly in the production of extreme speech that is claimed to be news. There are many information platforms on the Internet proclaimed as "news sites", but instead of conveying valuable information to the readers, they are used to circulate opinionated pieces and propaganda. The popularity of user-generated content - where users were enabled not only to consume but also to produce and to distribute digital content - used to be hailed optimistically as a form of democratization that will to give chances to citizens to voice their social, economic, political, and cultural concerns. However, the recent development shows that the freedom and the easy-access offered by the Internet have been used to propagate negative content and sectarian sentiments. This research conducts analysis of ten 'news outlets' that were banned by Indonesian government (KOMINFO) that had been considered spreading hatred and sectarian spirit. This research will examine closely this so-called news in terms of their content, tone, and the parties that are confronted through the content. This research argues that the once embraced users-generated content as alternative news by citizen had evolved to be a form of extreme speech propagator.
\end{abstract}

Keywords: News Productions, News Distributions, Extreme Speech, Sectarian

\section{Introduction}

The rise of the Internet as one of the primary medium of communication has brought significant changes in the ways in which information is produced and consumed. It is also undeniably give rise to a profound transformation in the practice of journalism. The Internet, on one hand, not only allows increasing speed of reporting and connects multiple forms and platforms to disseminate information in supporting the works of journalists; but, on the other hand, it is also brought challenges that lead to general decline of the quality of journalism. Nossek ${ }^{1}$ coins the term 'deprofessionalization of journalism' referring to the situation where "everyone can be a journalist and nobody actually is the one." [1] The deprofessionalization of journalism rings true in the Internet era nowadays when large circulated information is the output of non-professional actors as compare to the professional ones. This situation has challenged the authoritative position of professional journalists [2] that traditionally is known as the forefront producer of credible and trustworthy information.

The circumstance where professional journalists are not the sole producers of news has once embraced with optimism, when it brought forward the idea of citizen journalism. Citizen journalism is considered as the answer to filtering, framing, and gate keeping procedures that were practiced by many big media corporations, which often fueled by motivation to gain political and economic influences. There was hope that citizen journalists would 'tell the story as it is', without any ulterior motives. Continuous collaboration and verification of information among citizens [3] was hoped would generate high quality news that is comparable to the news produced by professional journalists. Admittedly, citizen journalism practices supported by the Internet at times have successfully produced and assembled diverse audience around specific interest. ${ }^{4}$ It also offered immediate information at the time when unexpected events took place. However, as it turn out, citizen journalism as an alternative news production to traditional journalism is rather difficult to sustain, as there is still no business model to make it viable. Phillips and Witschge [4] note that to run the high quality news production that would provide relevant information to the public is not inexpensive. Constant covering, verifying, and reporting every change of events in the world would need highly trained personnel and well-funded organization [4]. This very issue of difficulties in sustaining business model was the main problem that brought down OhMyNews

\footnotetext{
*Corresponding author: $\underline{\text { srmanalu@,fulbrightmail.org }}$
} 
International (an an example of once exuberant platform of citizen journalism) in 2010.

This situation just gets worse in the recent media industry transitions, where more and more unverifiable and false information is circulating on various networks of information. The term 'fake news' becomes so commonly used that it is even expressed when one disagree with information from others. Allcot and Gentzkow provide a clear understanding of fake news when they defined it as "news articles that are intentionally and verifiably false and could mislead readers." [5] From this definition we know that fake news involve an element of intention of the producers to mislead others.

The phenomenon of high circulating of false and fake news also took place in Indonesia. The increasing political freedom and the prevalent use of the Internet, mobile communication, and social media give rise to the high circulation of information, including unfortunately - the false one. In time when political events took place, such as general election, the circulation of information (including the false one) is expanding significantly. This is also the case in the Gubernatorial Election of Jakarta (the capital city of Indonesia) in 2016. The political contest for electing new leaders was tinged with racial and religious issues, which involved mobilization of large masses, both online and offline. The circulation of information that talked about issues of election as well as issues of religion on social media and various mobile applications is also notably high. Harian Kompas mentioned in February 26, 2017, that much of the false information related to Jakarta Gubernatorial Election incorporate some views expressing hatred that led to negative religious and racial sentiments. [6] Thus, the racial and sectarian issues became the main material for fabricated news with the intention to influence the outcome of the election.

In the heat of the spreading of false news in the country in 2016, the authority under the Ministry of Communication and Information Technology (MCIT) took action by banning a number of so called news portals that were deemed disseminating false news, not only related to the election, but also current affair information in general. Controversies were surged from this action. For some, this was a reflection of limiting the freedom of expression, but for some others it was a necessary action to maintain the unity of the country from the attempt to divide public into factions based on racial and religious sentiments. For the supporters of the banning the contents of those banned information portals comprise of the expression of hate and divisive notions.

The concept of hate speech often comes to the forefront of public debate as a concept that has regulatory aspect, in which it is forbidden because it stir up violence and prejudicial actions against particular group or individual. In many cases, this concept is also debatable as to what is the precise demarcation of hate speech, and the debate of when does free speech stop and hate speech begin?[7] Pohjonen and Udupta[8] offer a concept that similar to hate speech but put more emphasize on the practice of producing the speech and shifting from it regulatory feature. They introduce the concept of extreme speech with the "gesture toward the situatedness of online speech forms in different cultural and political milieus." [8] It is particularly used to see the circumstances where various online actors engage in online vitriol and the implication of the actions. The concept of extreme speech is used in this research as a framework to look closely on the practice of producing online content, particularly content generated by a number of users that is claimed as news but also is considered contain of fake news (hoax).

The continuity of false and fake news is undergone by Indonesia in 2018 which is not only targeting race and religion topics, but also natural disasters issue become main topic of fake news across Indonesia today. The low understanding of environmental issue makes Indonesia people gets easily regards the natural disaster news as official news from government.

\section{Methodology}

This research examines up to 43 web entries from nine (9) websites that have been banned by the Ministry of Communication and Information Technology (MCIT) Republic of Indonesia in mid of 2016. Those websites are; bisyarah.com; dakwahtangerang.com; gensyiah.com; islampos.com; kiblat.net; nahimunkar.com; postmetro.info; suaranews.com; voaislam.com. The content were coded according to the type of information, the tone of information, the sides or the parties confronted in content. This research also analyzes the likely motivation for distributing the information. This analysis is conducted to better understand the practice of news media or information production by non-professional that used be associated with democratization of media industry but have shifted to become the propagation of extreme speech that display the spirit of sectarianism and divisiveness..

\section{Discussion}

The analysis of the web portals shows that almost all of the content of the portals focus on the issues of religion, or the issues of social, economic, and political that related to the aspect of religion, particularly with Islam. A number of portals indicate explicitly that they are news portals. However, the content do not reflect any essential elements that can be counted as news. In the case where there is debate, or there are different stances on a particular issue, the information presented on the web portal is characterized by one sided of information. In other words, the information only covers one viewpoint without any clear effort to recognize or to acknowledge other different viewpoints. This one sided information is quite clear in the news coverage of legal case of Basuki Cahaya Purnama (the former Governor of DKI Jakarta), and in a number of critics regarding President Joko Widodo governmental performance. Other aspects of the information in the websites are the lack of verification and reliable source of information. A number of entries are clearly cited from different 
sources, but the information of the sources is vague and not stated clearly. The absent of these two elements in the information render the content of the web is more likely to be identified as opinion piece rather than news.

The explicit claim by the content creators that the information in those portals are news cannot be justified if we look at it through the Kovach and Rosenstiel [9] argument about news production by journalist. News productions through journalism involve a discipline of verification. In producing news, journalist should never adding anything that was not there, never deceive the audience, to be transparent about methods and motives, and rely on journalist own original reporting [9] Through this framework, we can see that the information in the web portals is far cry to what can be categorized as news.

In relation to the tone of the information, the portal entries presenting the tone that could be categorized as acrimonious and caustic speech, which could have implication on the polarization and division of readers. This can be clearly seen the information that related to the Syi'ah Muslim group, such as in the portal entry entitled, "Orang Iran Kencing di Masjid Nabawi!" (in English translation: Iranians urinate at Nabawi Mosque). The content of this entry is trying to degrade Syi'ah Muslim group (that is associated with Iran as the center of Syi'ah group) as the people who have respect of Nabawi Mosque that was establish by the Prophet Muhammad in Medina, Saudi Arabia. One of the comments of this entry even go as far saying that Syi'ah Muslim group could be liken to animal that deserve to be killed. The portrayal and the comment of the entry can be seen as de-humanizing member of other groups. Some other entries related to Syi'ah group are clearly invoke the sentiment of division that reinforce boundaries of in-group against out-group by attacking members from Syi'ah group.

Concomitant with the information tone, the web entries of most of the portals voiced the similar confrontational speech against a number of parties that clearly have different political of religious stances with the web content creators. The target of the confrontational speech in the portals can be categorized into three groups. The first group is the authority or government under the leadership of President Joko Widodo. The portal entries that show the confrontation to the authority can be seen in some entries, such as, " 'Silat Lidah' Kenaikan BBM" (Deceiving on the increasing of fuel price); "Mesranya Hubungan Penguasa \& Pengusaha, Rakyat Ditelantarkan (Lagi)!" (The intimate relationship between authority and businessmen, people are deserted, again); and "Indonesia Dibeli Cina" (Indonesia was bought by China). The second groups that is confronted through the content of portal entries are different faith group, such as Nahdatul Ulama and Syi'ah Muslim group. The Nahdatul Ulama group is considered distinct from a more conservative views owned by the content creators, and Syi'ah group has different religious root from the Sunni Muslim group point of view presented in the portal entries. The third groups that also confronted in the content of the portals are individuals who are considered to have liberal views such as Gunawan Muhammas and Ade Armando. This confrontation can be seen in the entries entitled, "Cara Goenawan Mohamad Jualan Marxisme dan Merusak Agama" (The way Gunawan Muhammad Selling Marxism and Ruining Religion), and "Kembali Berulah, Ade Armando Fitnah Zakir Naik Islamkan Orang dengan 'Settingan' (Make Trouble Again, Ade Armando Slander Zakir Nail Converted People to Become Muslim as Part of Act). Both of these entries are discrediting both Gunawan Muhammad and Ade Armando on their point of view regarding religion and a religious leader.

Regarding the fake news of natural disasters, Indonesia is combatting this phenomenon while managing to respond the major natural disaster happening throughout 2018, one for instance is Indonesia National Police have arrested six people across Indonesia who are suspected of sharing hoax stories on social media related to the recent natural disasters that have rocked various parts of the country that causes public unrest and panic related to the recent natural disasters. More than that, it misleads the understanding of environmental issue about natural disaster to unaware public.

The problematic nature of the content of these nine web portals indicate that instead of producing information with citizen point of views to complement news from media companies, information from nonprofessional journalists can lead to a production of extreme speech that feature acrimonious and caustic speech, which can lead to faction and division in public. The fact that some entries were positioned as news although those are more of opinion and commentaries render these entries can be categories as disinformation. Fallis [10] identified there are two characteristic of false news. The first one is disinformation, or false information that intentionally created to deceive others. The second is misinformation, or incorrect as a result of omissions, errors, and biases [10]. By this definition we can categories most of the entries of these portals as false news.

\section{Conclusion}

This article argued that new media provide access to produce alternative news from the one offered by mainstream or more established media. However, instead of producing verified account of information from different angle, this alternative source of information are committed to spread extreme speech contain of acrimonious and polarizing information and distributed disinformation of false news. The content creator of these portals promote the extreme speech by producing content that undermining the authority, weaken credibility of other religious group, dehumanizing people with different religious values, and discrediting individuals with more liberal religious and political stance. 


\section{References}

1. H. Nossek, "On the future of journalism as a professional practice and the case of journalism in Israel", Journalism, 10(3), 358-61 (2009).

2. P. Lee-Wright, A. Phillips and T. Witschge, "Introduction", Changing Journalism, Routledge, London $\square$ (2012).

3. A. Bruns, "Produsage: Towards a Broader Framework for User-Led Content Creation", Paper presented at Creativity \& Cognition conference, Washington D.C, USA, 13-15 (2007).

4. A. Phillips and T. Witschge, "The changing business of news: Sustainability of news journalism", Changing Journalism, Routledge: London (2012).

5. H. Allcott, and M. Gentzkow, "Social Media and Fake News in the Election 2016", Journal of Economic Perspectives., 32 (2) 211-236 (2017).
6. Harian Kompas, "Hoaks: dari Era Soekarno Hingga Kini”, Kompas, Minggu, 26 Feb (2017).

7. E. Volokh, Washington Post article (5 May 2015), No, there's no "hate speech" exception to the First Amendment (2015).

8. M. Pohjonen and S. Udupa, Extreme Speech Online: $\square$ An Anthropological Critique of Hate Speech Debates, International Journal of Communication 11, pp. 1173-1191 (2017).

9. B. Kovach and T. Rosenstiel, The Element of Journalism: What Newspeople Should Know and the Public Should Expect, Three Rivers Press: New York $\square$ (2012).

10. D. Fallis, "What Is Disinformation?" in Ken Herold (Ed.) Library Trends: Exploring Philosophies of Information, 63 (3) 401-426 (2015). 